\title{
INFLATION AND THE INFORMATIVENESS OF PRICES: MICROECONOMIC EVIDENCE FROM HIGH INFLATION*
}

\author{
Mariano Tommasi**
}

\section{Resumo}

O texto analisa os efeitos da inflação solıre a capacidacle clos agentes preverem preços reais, ntilizando daclos niicroeconômicos para a Argentina no período 19901992. A evilência sugere que a inflação degrada o conterído informacional dos preços reais. Mostra-se que a performance de cliversas regras de previsão de preços reais piora quando a inflação aumenta. Além clisso, os preços reais mulam com mais freqiiência e as liquidaçōes desaparecem. Issso sugere que a inflação (pelo menos a inflação elevada) acarreta efeitos de "Organização Industrial" commmente ignorados em avaliaçōes macroeconôninicas dos efeitos da inflação.

\section{Abstract}

I study the effect of inflation on the ability of economic agents to forecast real prices, using microeconomic data from Argentina 1990-1992. The evidence favors the view that inflation degrades the informational content of real prices. Several rules for forecasting real prices are shown to perform worst at higher inflation. Also, at high inflation, real prices have shorter durations, and mark-down sales disappear. This suggests that inflation (at least high inflation) has "Industrial Organization" effects usually ignored in macroeconomic assessments of the effects of inflation.

* I received valuable comments and suggestions from Larry Ball, Roland Benabon, Stanley Fischer, Martin Kanfman, Sanl Lach, Carl Lnndgren, laime Marqquez, David Parsley; Simon Potter, Julio Rotemberg; Kennkwan Ryı, Amna Schwartz, Hillary Sigman, Dani Tsiddon, fon anomymous referees, and seminar participants at the NBER Monetary Economics meeting, the AEA meetings and the Western Economic Association meetings. This paper was started while the anthor was with the Department of Economics at UCLA and contimed at the Kemnedy School of Govermment at Harvard. I thank the UCLA Academic Senate and the National Burean of Economic Research for financial support.

** Universidad de San Andrés, Vito Dumas 284, 1644 Victoria, Bnenos Aires, Argentina. E-mail: tommasi andesa.edn.ar

\begin{tabular}{lllll}
\hline R. de Econometria & Rio de Janeiro & v. 16, $\mathrm{n}^{\mathrm{O}}$ & 2, pp. 37-75 & Novembro 1996 \\
\hline
\end{tabular} 
Pala.vross-Chave: Inflation, informativeness, pricing rnles, forecasting

Código JEL: D4, D83, E31, L16

\section{Introduction.}

Inflation, we are told, affects the workings of the price system. Friedman (1977), in his Nobel Lecture, hypothesized that increased volatility of inflation reduces the efficiency of market prices as coordinators of economic activity via an "increased amount of noise". Fischer (1981) argued that "inflation is associated with relative price variability that is unrelated to relative scarcities and hence leads to misallocations of resources". As Ball and Romer (1992) stress, prices have two roles: guiding allocations and providing information. Both roles are clearly interwined, and several authors have argued that inflation, by affecting information, worsens the allocation of resources. For example, Reagan and Stultz (1993) argue that price instability raises the costs of contracting and lowers economic efficiency. Huizinga (1993) argues that relative price uncertainty can reduce investment - uncertainty about the net present value of investment projects can make firms reluctant to incur costly, irreversible capital outlays. Tommasi (1994) argues that as current prices become poor predictors of future ones, agents optimally decide to be less informed, and more inefficient transactions occur - for instance, inefficient firms may be able to survive in an environment of price ignorance.

An extensive literature has linked aggregate inflation and inflation uncertainty with measures of "relative price variability" (RPV). Cukierman (1983), Marquez and Vining (1984), and Palerm (1990) survey the "macro" literature, while Weiss (1993) reviews the more recent "micro" findings. That empirical literature used measures 
of price variability that, although interesting in their own right, ${ }^{1}$ did not directly address the question of the informational content of prices. Prices can be highly variable yet very predictable - and hence very informative.

In this paper, I try to look directly into the informational content of real prices under different inflation regimes. I use microeconomic evidence (grocery prices) from a high-inflation case: Argentina 19901992. The evidence favors the view, in Carlton (1982), that "inflation degrades the informational content of real prices".

Prices are indicators of characteristics of the good and of the seller, which are important because they can affect the ex-post value of today's purchase and the value of repeated purchase from the same supplier. Given that my data set consists of grocery prices I concentrate on the latter, the information that today's prices provide about future prices. Operationally, I study the forecastability of real prices under different inflation regimes. The reader may wonder why is this necessary if we already know that higher inflations tend to be associated with increased RPV. As stated before, there is not a one to one correspondence between the measures of RPV employed in the literature and the informativeness of prices. Imagine a world in which half the sellers (those located in streets that run North-South) increased their prices by $20 \%$ in odd periods, while the other half did so in even periods. Imagine that this pattern has been in place for a long time, and it is hence known by buyers. Then, measured relative price variability will be $10 \%$ although the prices observed today will be fully informative about the future. Imagine at the other end that every sellers throws a coin to decide whether or not to increase his nominal price by $10 \%$. In that case RPV will be only $5 \%$, but today's prices will be much less revealing than in the previous example.

1 See Fartman (1901) for a critiq̨ue of some of this literature. An extensive survey is provided by Golols (1993). Ungar and Zilberfarb (1993) is a more recent paper on the umpredictability of aggregate inflation. In this paper I concentrate on the mpredictability of individual prices. 


\section{The Data.}

The data used in this study consist of weekly price quotes from 5 supermarkets within the same neighborhood in the Federal District of Buenos Aires, Argentina, collected by the Secretaria de Comercio. The original sample contained 15 products, from which I selected the 10 with low number of missing values: butter, coffee, flour, laundry detergent, oil, peas, tea, tomato sauce and yerba (a typical Argentina beverage, similar to tead). Each good is completely homogeneous across stores, a particular brand/quality; for instance, "coffee" is a particular brand and size of instant coffee. The series run for 46 weeks in 1990 (February-December), two sets of 12 weeks in 1991 (January-April and September-December), and 30 weeks in 1992 (April-November). Statistics for aggregate inflation are provided in Table $1 .^{2}$

Table 1

\begin{tabular}{|cc|c|c|}
\hline \multirow{2}{*}{ Period (Weeks) } & Average Weekly II & Std. Dev. of II \\
& & & \\
\hline 1990 & Feb-May (15) & $8.80 \%$ & 16.51 \\
& Nay-Aug (15) & $1.08 \%$ & 1.59 \\
& Aug-Dec (15) & $1.22 \%$ & 1.37 \\
\hline 1991 & Jan-Apr (12) & $3.88 \%$ & 6.81 \\
& Sep-Dec (12) & $0.03 \%$ & 0.98 \\
\hline 1992 & Apr-Nov (30) & $0.29 \%$ & 1.08 \\
\hline
\end{tabular}

The annual inflation rate in Argentina was of the order of $5000 \%$ in $1989,1300 \%$ in $1990,85 \%$ in 1991 , and $18 \%$ in 1992 . On April 1991

2 I have experimented using different constructions for the aggregate price index and for inflation: one from an indepenclent inflation sample (from Instituto de Politica Economica $y^{\prime}$ Social), and another using intrasample data with CPI weights, without substantive changes in the results. In the paper I report the data using the non-weighted intrasample measure of inflation. Figure 2 contains a plot of the weekly inflation rate for the sample period. 
the government adopted a fixed exchange rate with the U.S. dollar. The "Convertibility Law" was the corner-stone of a new and desperate stabilization program devised to put an end to a history of almost 50 years of rates of inflation well above international standards which climaxed in two hyperinflation accelerations during April-July 1989 and December 1989-March 1990.

In most of the paper I will be looking at the behavior of individual prices across inflation "regimes". I will use average weekly inflation to characterize each period, but in this as in most inflation experiences, inflation variability - and quite likely inflation uncertainty - are positively correlated to average inflation." The "regimes" I use are: February-May 1990, May-August 1990, August-December 1990, January-April 1991, September-December 1991, and AprilNovember 1992. In exploratory work when I only had the 1990 data (Tommasi 1993), I concluded that it was best to characterize that sample into the three 15 -week episodes. The first 15 weeks are clearly distinct, since it is a hyperinflation period. I chose to treat the other two subperiods separately since prices might behave differently right after hyperinflation than when stability is more consolidated. The results of the paper do not change if we use alternative partitions of the 1990 data. With respect to 1991 we did not have many options, as we only had to non-contiguous sets of 12 weeks. We explored partitioning the 1992 data into two subperiods, and the results do not change. It is worth noting at the outset, that the results are not driven by the two hyperinflation episodes. As you will see in Figure 1, the results are fairly monotonic.

In the next section, I explore the impact of macroeconomic instability, as measured by different inflation environments, on the ability of economic agents to forecast future prices, using several forecast rules.

3 See Ball and Cecchetti (1990): Evans (1991) and Evans and Wachtel (1993) for recent studies of the links between inflation rate and inflation - and regime - uncertainty. 


\section{Inflation and the Informativeness of Prices.}

The exercise in this section consists on generating a forecast of future prices from past information, and then evaluating how that forecast performs in the different inflation regimes. The Section 3.1 looks at autoregressive models. Section 3.2 uses insights firom the literature on costs of price adjustment and uses $(S, s)$ forecasts. Section 3.3 looks at deviations from "warranted" prices and Section 3.4 compares and summarizes the information from the different forecast rules. Sections 3.5 and 3.6 provide additional information on the "IO" effects of inflation, by looking at the durability of real prices, and at the effect of inflation on the presence of mark-down sales.

\subsection{Autocorrelations of real prices.}

As a first forecast rule, following the literature on consumer research (Winer, 1986), we look at an extrapolation of past real prices. ${ }^{4}$ In the next section we will look at forecast rules that take explicitly into account the intermittent change in nominal prices that emerges from costs of price adjustment.

Let $P_{i j,}$, be the price of good $i$ and store $j$ at time $t$. Let $P_{l}=$ $\frac{1}{50} \sum_{i=1}^{10} \sum_{j=1}^{5} P_{i, j t}$ be the price index at time $t$. Also, let $Z_{i, j t}=$ $\ln \frac{P_{i j t}}{P_{t}}$, be a measure of real price.

4 Literature on consmuer research generally assumes (with reasonable empirical success) that consumers extrapolate the past observed price, adjusting for trend, in this case aggregate inflam tion. In most of the analysis I will be assuming knowledge of average inflation - in high inflation situations; people tend to be quite informed abont the evolution of the exchange rate, and estimates of aggregate infiation are released at high frequency (that is the reason why the data being used have been collected). Also, insofar as price takers have to forecast real prices with imperfect information abont aggregates, I au ignoring an extra informational difficulty in favor of the hypothesis of this paper: higher inflation enviromnents make forecasting of real prices very difficult. More on this later. 
The time series properties of the 50 series $Z_{i, j t}$ were analyzed by looking at the partial autocorrelations. This suggested describing its behavior by the $A R(1)$ process: ${ }^{5}$

$$
Z_{i j t}=\rho_{i j} Z_{i, j t-1}+\varepsilon_{i, j t}
$$

Table A1 provides the estimated values of $\rho$ and $t$-statistics for each product-store pair for each of the 6 episodes. Correlation coefficients tend to be lower in periods of higher inflation. Table 2 summarizes this information. (All the tables in the text are organized by ascending order of inflation, rather than chronologically.) As a quick check for significance, I regressed (across the 6 regimes) average $\rho$ from Table 2 on a constant and inflation. The coefficient on inflation is -.047 and the $t$-statistic is -11.08 , significant at the 1 percent level.

The information in Tables $A 1$ and 2 suggests that the higher the aggregate macroeconomic instability (inflation), the harder it is to make predictions about future values of real prices. ${ }^{6}$

5 The analysis has been reprodnced using richer AR specilications. The forecast ability is no better than the AR (1), and the results across inflation regimes are consistent witl those in the AR (I) case.

6 A similar finding was reported in Tommasi (1993, Section j). There, aside from having a shorter sample, the emphasis was on the deviation of the price at a particnlar store with respect to the product average. Following the search literature, I suggested that the ability of buyers to identify "low price sellers" was declining in inflation. 
Inflation and the informativeness of prices

\section{Table 2}

Correlation of Real Prices over Time

(10 goods $\times 5$ stores $=50$ cases $)$

\begin{tabular}{|l|c|c|c|c|c|c|}
\hline \multicolumn{1}{|c|}{ Period } & 91II & 92 & 90II & 90III & 91I & 90I \\
\hline Weekly Inflation (\%) & 0.03 & 0.29 & 1.08 & 1.22 & 3.88 & 8.80 \\
Average & 0.78 & 0.73 & 0.69 & 0.65 & 0.60 & 0.33 \\
\% Cases Signif. (.05) & 88 & 92 & 82 & 78 & 68 & 28 \\
Average MSE & 0.038 & 0.040 & 0.052 & 0.086 & 0.139 & 0.125 \\
\hline
\end{tabular}

Note: In this and all subsequent tables:

90I : 15 weeks (Jan-May 1990)

90II : 15 weeks (May-Aug 1990)

90III: 15 weeks (Aug-Dec 1990)

91I : 12 weeks (Jan-Apr 1991)

91II : 12 weeks (Sep-Dec 1991)

92 : 30 weeks (Apr-Nov 1992)

Still, the estimate of $\rho$ provides only information about the slope of a regression of $Z_{i, j l}$ on $Z_{i, j t-1}$. It may be the case that a smaller slope does not necessarily mean less information. If agents knew for sure that the deviation of tomorrow's price from some average price will be exactly $33 \%$ of today's deviation, there will be full information in spite $\rho=.33$. This suggests looking at the forecast error from such $A R(1)$ rule. To do that, we look at the standard error of the regression $(S E R)$ or mean squared forecast error $(M S E)$ :

$$
M S E_{i, j}=\left\{\sum_{t}\left(Z_{i, j t}-\hat{Z}_{i, j t}\right)^{2} /(T-I K)\right\}^{\frac{1}{2}}
$$


where $K$ stands for degrees of freedom, and $\widehat{Z}_{i, j t}=\widehat{\rho}_{i, j} Z_{i, j t-1}$.

The values of $M S E_{i j}$ for the 50 cases are reported in Table $A 1$. The last row in Table 2 presents the average $M S E$ for each time period (inflation regime). The evidence suggests forecast errors increasing in the inflation rate, consistent with a negative effect of inflation on information. Regressing average $M S E$ on average inflation across the 6 regimes, we obtain a coefficient of .01 on inflation, with standard error .004 and $t$-statistic of 2,65 , significant at the 5 percent level.

Given that all the products were sold in the same stores (supermarkets), it may be the case that buyers do not care about the prices of individual items, but at the price of a "bundle" they purchase. In that case, what matters is the predictability of the price of the bundle. To analyze the impact of inflation on the price of a composite commodity, I constructed a price index per store, $P_{j}$, and regressed the equivalent of equation (1), now on the composite, as opposed to individual goods. I worked with both a weighted average (using weights from CPI) and unweighted average. I report in Tables A2 and 3 the results for the unweighted bundle; the results with weights are similar.

\section{Table 3}

Correlation of Real Prices over Time

(bundle of goods, 5 stores)

\begin{tabular}{|l|l|l|l|l|l|l|}
\hline & & & & & & \\
\hline Inflation (\%) & 0.03 & 0.29 & 1.08 & 1.22 & 3.88 & 8.80 \\
Average $\rho$ & 0.84 & 0.90 & 0.84 & 0.87 & 0.79 & 0.65 \\
Average MSE & 0.017 & 0.015 & 0.020 & 0.021 & 0.028 & 0.041 \\
\hline
\end{tabular}

Revista de Econometria 16 (2) Novembro 1996 
Notice that, not surprisingly, there is much less volatility at the level of "bundle" than at the level of individual product. To some extent, this is just an artifact of aggregation. ${ }^{7}$ Once more, the evidence indicates a worsening of forecasts at higher inflation rates. The regression coefficient of inflation is - $-.025(.004)$ for average $\rho$ and of $.0028(.0002)$ for average $M S E . t$-statistic are -6.96 and 15.77 , in both cases highly significant.

\section{2. $(S, s)$ pricing rules.}

So far we have looked at correlations of real prices over time, and at second moments of these linear predictors. Of course, it may be the case that price expectations are formed differently. For instance, stores may follow a particular pricing rule, and consumers may be aware of that and from their expectations accordingly. A sizable theoretical and empirical literature emphasizes the presence of nominal price regidities at the microeconomic level (and its implications both at the micro and macro level). ${ }^{8}$ The most common pricing rule in the literature, is the $(S, s)$ pricing policy, analogous to the solution

7 For details on this, see Section 2.1 - "The effects of aggregation" in Lach and Tsiddon (1990). I experincuted with "random" bundles (using different goods from different stores) and the results are similar to those in Tables $A 2$ and 3.

8 Mankiw (1985), Akerlof and Yellen (1985̃), Parkin (19S6) and Blanchard and IKiyotaki (1987) argue that frictions in price adjustment at the level of individual firms have important implica. tions for the effect of aggregate demand on aggregate activity, one of the central cluestions in macroeconomics. See Mankiw (1990) and Caplin (1993) for recent surveys of theoretical eflorts to integrate nominal rigidities at the micro level into macro relationships, and Weiss (1993) for a recent survey of empirical studies of priciug policies by individual firms, as well as for further references. 
to the dynamic inventory problem (Scarf (1959)). ${ }^{9}$ Firms set nominal prices to induce an initial real price $S$, and then let inflation erode its real price up to $s$, before changing the nominal price again. The bounds are chosen to minimize the loss of being away from an optimal real price plus the cost of the nominal change. We assume in what follows that consumers are aware of those pricing policies, and hence we look at $(S, s)$ forecast rules.

Define real prices as $R_{i j t}=P_{i j t} / P_{t}$. We will be assuming that for each period (inflation regime), seller $j$ selects the bounds $S_{i j}$ and $s_{i j}$ within which the real price of product $i j$ will be allowed to fluctuate. In constructing consumers' estimates, I assume that they know or estimate the bounds to be the order statistics $\widehat{S}_{i j}=$ $\max \left(R_{i j t}\right)$, and $\widehat{s}_{i j}=\max \left(R_{i j t}\right)$ for each period under analysis. ${ }^{10}$ Also, I assume that consumers (and firms) know the realization of aggregate inflation at any point in time. This is obviously not true, but explicit consideration of the difficulties of predicting real prices in an environment of aggregate uncertainty could only strenghten the point of the paper: the higher the macro uncertainty, the harder it is to forecast real prices.

\section{- $(S, s)$ rules with one price change.}

Bonomo (1994) shows that $(S, s)$ policies are optimal only when all the shocks are positive and they are very close to optimal when

9 Sheshinski and Weiss (1977) and (1983) are the classical reference. Caplin and Spulber (1987), Caballero and Engel (1991), and Caplin and Leahy (1991) address the question of aggre gation; i.e., the behavior of the aggregate price level and aggregate output in economies populated by furms following $(S, s)$ pricing policies. Cecchetti (1986), Lach and Tsiddon (1992), and Fisher and Konjeczny (1993) are empirical studies of $(S, s)$ policies at the microeconomic level. Cecchetti (1985) provides a methodology for measuring frequency of price changes in order to test the relevance of assuming prices to be set for discrete periods of tirne at overlapping intervals.

10 See Flinn and Heckman (1982) for the fast convergence properties of these estimators. Other estimations of $S_{i j}$ and $s_{i j}$, such as minimization of mean squared error were explored, without substantial changes in the results. 
the average inflation rate is large relative to its variability. The literature has tended to use $(S, s)$ rules as an approximation to optimal rules in more general cases (see Caplin and Sheshinski 1987 and Blanchard 1990). Lach and Tsiddon (1992) and Ferreira (1995) suggest that $(S, s)$ rules are good approximations to the behavior of prices in inflationary environments (for the cases of Israel and Brasil, respectively).

Imagine that sellers are following an $(S, s)$ rule, with bounds chosen as a function of the inflation ratie, ${ }^{11}$ and that consumers know the average inflation rate. In this section ive assume that (consumers from their forecast believing that) nominal prices change at most once between observations. In the next section we extend to more general forecasts.

The forecast will consider two possibilities. If inflation this period was quite low or if last real price observation was quite high, we except the nominal price to be the same of last observation, and hence the real price will be $R_{i j t-1}\left(P_{t-1} / P_{t}\right)$. If inflation was high enough or last observation low enough, we except a nominal price change. Let $\tau \in(t-1, t)$ be the exact moment at which the real price hits $s$, so that

$$
s=R_{i, j-1}\left(P_{t-1} / P_{\tau}\right)
$$

and

$$
P_{\tau}=R_{i j t-1}\left(P_{t-1} / s\right)
$$

At that moment, the nominal price is adjusted to induce a real price $S$. From $\tau$ to $t$, it depreciates by $\left(P_{\tau} / P_{t}\right)$. Hence

$$
\widehat{R}_{i, j t-1}=S\left(P_{\tau} / P_{t}\right)=\frac{S}{s} \frac{P_{t-1}}{P_{t}} R_{i, j t-1}
$$

11 We assume that each period muder analysis represents an inflation regine, i.e., the same infiation process. This seens a reasonable assmnption for all the periods under analysis (1990 was split into three relatively homogeneons subperiods, 1992 is quite stable) except perhaps for the first 12 weeks in our 1991 sample, but the results do not change if we exchnde that period. 


\section{Mariano Tommasi}

So that the forecast or real price will be given by

$$
\widehat{R}_{i, j t}=\left\{\begin{array}{lll}
R_{i, j t-1}\left(P_{t-1} / P_{t}\right) & \text { if } \quad R_{i, j t-1}\left(P_{t-1} / P_{t}\right) \geq \widehat{s}_{i, j} \\
\left(\widehat{S}_{i, j} / \widehat{s}_{i, j}\right)\left(P_{t-1} / P_{t}\right) R_{i, j t-1} & \text { if } \quad & R_{i, j t-1}\left(P_{t-1} / P_{t}\right)<\widehat{s}_{i j} .
\end{array}\right.
$$

The Mean Squared forecast Errors

$$
M S E_{i, j}=\left\{\sum_{t}\left(R_{i, j t}-\widehat{R}_{i, j t .}\right)^{2} /(T-K)\right\}^{\frac{1}{2}}
$$

and Mean Average forecast Errors (a criterion less sensitive to outliers)

$$
M A E_{i, j}=\left\{\sum_{t}\left|R_{i, j t}-\widehat{R}_{i, j t}\right| /(T-K)\right\}^{\frac{1}{2}}
$$

from forecast rule (3), were computed for each $i j$, for each inflation regime. Table 4 summarizes the MSE and MAE information. The MSEs and MAEs of each product/store were normalized by the mean (hence expressed in percentage, unit free, terms) before averaging.

Table 4

$(S, s)$ Rule with One Price Change

\begin{tabular}{|l|l|l|l|l|l|l|}
\hline & & & & & & \\
\hline Inflation (\%) & 0.03 & 0.29 & 1.08 & 1.22 & 3.88 & 8.80 \\
Average \% MAE & 0.032 & 0.016 & 0.050 & 0.049 & 0.060 & 0.165 \\
Average \% MSE & 0.051 & 0.041 & 0.068 & 0.079 & 0.079 & 0.217 \\
\hline
\end{tabular}

Analogous to the findings of previous sections, forecast errors are increasing in the inflation rate. Inflation is significant in the explanation of average MSE, at the 1 percent level ( $t$-statistic 6.67). 


\section{- Other $(S, s)$ rules.}

The results of Table 4 can be criticized on the grounds that an $(S, s)$ algorithm that allows for only one price change will tend to induce a bias to excessive errors in cases of very high inflation. (If weekly inflation is larger than the percentage difference between $S$ and $s$, stores will change prices more than once a week, and hence the error from forecast rule (3) will be too large).

To account for that possibility, recursive versions of (3), allowing for 2 and 3 price changes were studied. (Given that the lowest $(S, s)$ range was of the order of $20 \%$ and that the highest inflation was of $40 \%$, more than 3 price changes seemed unnecessary). Those rules did not represent a substantial improvement over the simpler one, and the results also showed errors to be larger in episodes of higher inflation. ${ }^{12}$

One could also argue that even if firms were following textbook $(S, s)$ rules, it seems unlikely that price taking agents (buyers) in these markets will go over such sophisticated computations. In order to compare the performance of relatively simpler rules, the following option was explored:

$(S, s)$ with "bounded rationality" rule: If a first stage, use forecast rule (3). If the forecast $R$ is greater than or equal to $\widehat{s}_{i j}$, use that forecast. Otherwise, forecast $R$ to be the mid-point of the band, $\left(\widehat{S}_{i, j}+\widehat{s}_{i, j}\right) / 2$.

12 Notice that a recursive version of (3) is equivalent to rule that allows for any ummber of adjustments. Bonomo and Najluerg (1993) show that this more general rule is:

$$
\widehat{R}_{i j t}=\left\{\begin{array}{lll}
R_{i, j t-1}\left(P_{t-1} / P_{t}\right) & \text { if } \quad R_{i, j t-1}\left(P_{t-1} / P_{t}\right) \geq \widehat{s}_{i, j} \\
\left(\widehat{S}_{i, j} / \widehat{s}_{i, j}\right)^{n}\left(P_{t-1} / P_{t}\right) R_{i, j t-1} & \text { if } \quad R_{i, j t-1}\left(P_{t-1} / P_{t}\right)<\widehat{s}_{i, j}
\end{array}\right.
$$

when $n=\left\{\max z \in Z^{+}:(s / S)^{z} \leq\left(P_{\tau} / P_{t}\right)\right\}$. For large values of inflation, this rule did worse than the rule we present below. 


\section{Mariano Tommasi}

The MSEs and MAEs from this rule for the 50 product/stores were computed. The unit-free averages are reported in Table 5.

\section{Table 5}

$(S, s)$ Rule with "Bounded Rationality"

\begin{tabular}{|l|l|l|l|l|l|l|}
\hline & & & & & & \\
\hline Inflation (\%) & 0.03 & 0.29 & 1.08 & 1.22 & 3.88 & 8.80 \\
Average \% MAE & 0.031 & 0.016 & 0.051 & 0.050 & 0.067 & 0.148 \\
& & & & & & 0.096 \\
Average \% MSE & 0.049 & 0.042 & 0.081 & 0.079 & 0.092 & 0.186 \\
\hline
\end{tabular}

Once once, predictive power is lost at higher inflation rates. The $t$-statistic for inflation in the regression explaining MSE is 8.12. Comparing with Table 4 , this rule does a little better at very high inflation. I discuss a more general comparison across forecast rules in Section 3.4. ${ }^{13}$

\subsection{The excess variability of relative prices. ${ }^{14}$}

Excess price variability is likely to have negative effects on the workings of the price system for at least two reasons, relating to the two roles of prices: allocation and information. First, the allocational role of prices is affected if prices are away from fundamentals. Second, if current prices are less revealing about future ones (i.e.

13 Notice that I have used only one sided $(S, s)$ rules. It is possible that firms can be following two-sided rules. The likelihood of that depends on tbe relative importance of the common upward drift vis-a-vis the importance of idiosyncratic shocks and possibility of deflation. Intuitively, it is more likely that firms follow two-sided rules during episodes of low inflation. In that case, my estimates of forecast errors might be upward biased in the low inflation cases, working against my hypothesis.

14 I am indebted to Stanley Fischer for suggestions that lead to this section. 
its informational role is affected), further distortions arise (Ball and Romer 1992, and Tommasi 1994). Most of the paper so far has concentrated on the second point: inflation diminishes the information about future real prices contained in current ones. In this section, I present a measure of the deviation of real prices at any point in time from their "correct" level.

According to Fischer (1986), in order to assess the (negative) impact of inflation-induced price variability on the workings of the price system, one wants a measure of divergence of the price of the good from its "correct" price. In order to construct such a measure, I assumed the "warranted" price for each good/store in each episode to be the average $R_{i, j}=\sum R_{i, j t} / T$ of that period. From there, I constructed as measure of excess price variability, the coefficient of variation of $R_{i, j t}$ around $R_{i, j}$. The same exercise is performed at the level of product average $R_{i}$ (as opposed to product/store $R_{i, j}$ ). The numbers are provided in Table $A 3$ and summarized in Table 6.

\section{Table 6}

Excess Variability of Real Prices

Coefficients of Variation

$$
C V_{i, j}=\left[\sum_{t}\left(R_{i, j t}-R_{i, j}\right)^{2}\right]^{\frac{1}{2}} / R_{i, j}
$$

\begin{tabular}{|l|l|l|l|l|l|l|}
\hline & & & & & & \\
\hline Inflation (\%) & 0.03 & 0.29 & 1.08 & 1.22 & 3.88 & 8.80 \\
Average $C V_{i, j}$ & 0.059 & 0.076 & 0.068 & 0.072 & 0.108 & 0.154 \\
Average $C V_{i}$ & 0.036 & 0.038 & 0.049 & 0.049 & 0.038 & 0.115 \\
\hline
\end{tabular}

Not surprisingly, excess price variability is increasing in the inflation rate. Regressing $C V_{i, j}$ on the average inflation and a constant, the inflation coefficient is significant at the 1 percent level ( $t$ of 11.35). The same is true for $C V_{i}$, with a $t$-statistic of 4.01 . 


\section{Mariano Tommasi}

I have reproduced this exercise using as alternative proxies for the "warranted" price: (i) the average price of the good across stores in that period, and (ii) that average corrected for the average markup charged by each store. The results are the same.

\subsection{Comparison of forecast rules.}

In turns out that the measure of excess variability of relative prices $C V_{i, j}$ is equivalent to the MSE of a forecast rule where the price consumers expect to find at any point in time is the period average $R_{i, j}$. Hence, we have reported 4 different forecast rules. In this section, I provide a brief comparison across forecast rules.

Table 7 summarizes the averages of MSE for the 4 forecast rules in the 6 episodes under analysis.

\section{Table 7}

Average Mean Squared Error

Different Forecast Rules

\begin{tabular}{|l|l|l|l|l|l|}
\hline$\pi_{t}$ & Period & AR (1) & Ss(1) & Ss+br & Ct. \\
\hline 0.03 & $91 \mathrm{II}$ & 0.038 & 0.051 & 0.049 & 0.059 \\
0.29 & 92 & 0.040 & 0.041 & 0.042 & 0.076 \\
1.08 & $90 \mathrm{II}$ & 0.052 & 0.068 & 0.081 & 0.068 \\
1.22 & $90 \mathrm{III}$ & 0.086 & 0.079 & 0.079 & 0.072 \\
3.88 & $91 \mathrm{I}$ & 0.139 & 0.079 & 0.092 & 0.108 \\
8.80 & $90 \mathrm{I}$ & 0.125 & 0.217 & 0.186 & 0.154 \\
\hline
\end{tabular}

\section{Note:}

AR(1): \% MSE from Table 2

Ss(1): \% MSE from Table 4

Ss+br: \% MSE from Table 5

Ct. : $C V_{i, j}$ from Table 6

(MSE from a constant prediction equal to the mean $R_{i, j}$ ) 
The information, plotted in Figure 1 shows that all the forecast rules perform worse at higher inflation. In terms of relative performance, $A R(1)$ seems the best on average. It has a better relative performance in periods of low inflation and of hyperinflation and a worse performance in periods of high inflation. $(S, s)$ rules have a better relative performance at high inflation, a reasonable performance at low inflation, but they perform poorly during hyperinflation. This provides some preliminary evidence in favor of the view (in Leijonhulfvud 1991, Heiner 1983 and Heymann and Leijonhulfvud 1993) that as the macreconomic environment becomes very complex (extreme price instability) simpler expectation-formation rules start performing relatively better than more sophisticated rules based on economic models.

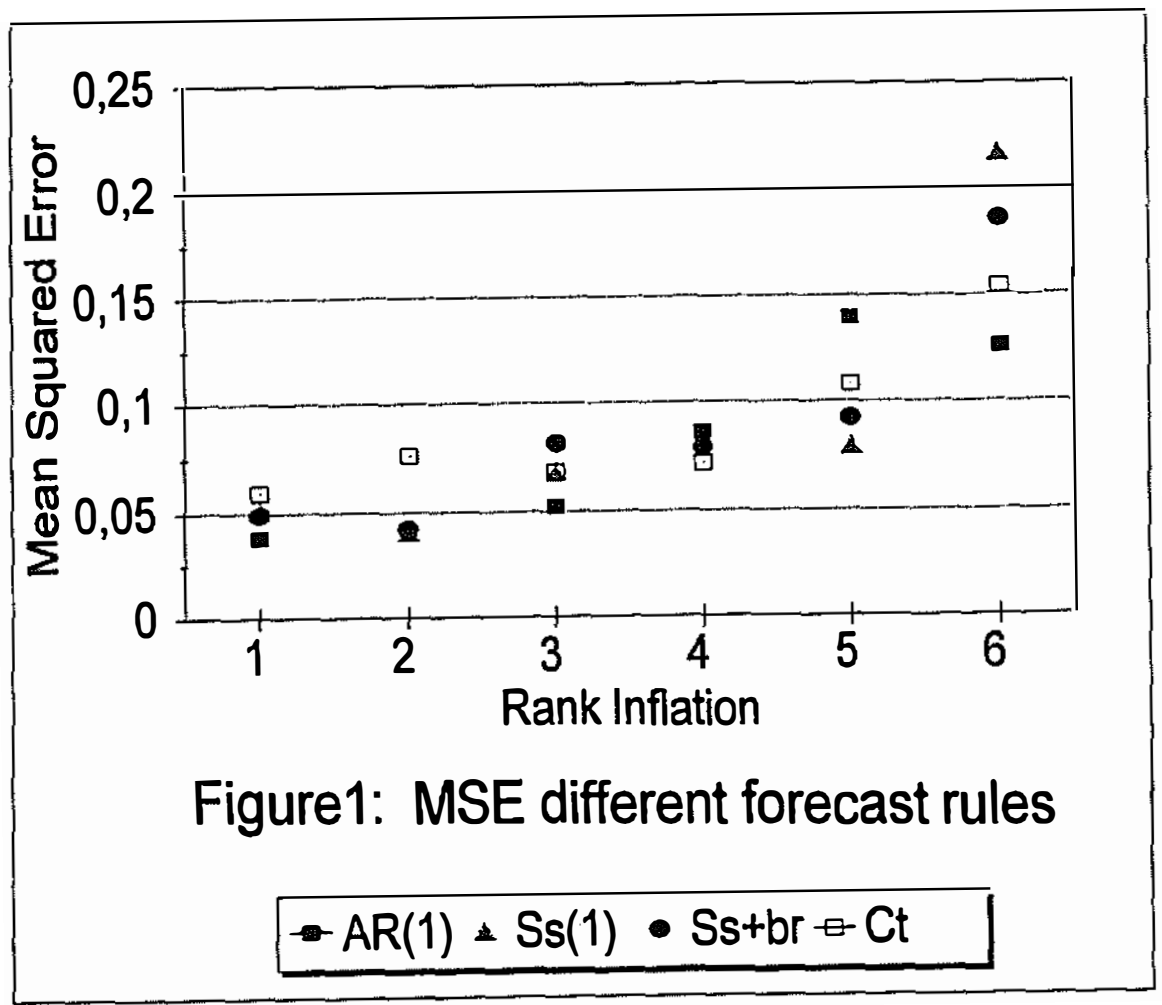




\subsection{The durability of price information.}

In the context of equilibrium models of imperfect price information with intertemporal purchases, such as those in Benabou (1993), Fishman and Rob (1991), McMillan and Morgan (1988), and Tommasi (1994), one very important parameter is the duration of real prices - the number of periods that a real price is below a particular threshold. Fishman and Rob (1991) and Tommasi (1994) show that consumer welfare and economic efficiency are increasing in that duration. The same result is obtained by Ball and Romer (1992) in a different (non-search) context.

The intuition is as follows. Imagine a consumer who buys a particular product once a week. In a context of unchanging real prices, the buyer will search for an adequate supplier (defined by a reservation acceptance price) the first time, and stick to purchasing there forever. In a changing environment, it is optimal (under some conditions) to set a reservation acceptance price and keep purchasing from the same supplier as long as his real price is below that threshold. An increase in real price instability harms consumers by lowering the value of the information they have costly acquired. The equilibrium implications of price instability are lower consumer welfare and a less effective selection of adequate trading partners.

To provide some evidence on price durability, I computed the number of consecutive weeks in which each real price is below a certain threshold. I did so far several thresholds, I report here the average number of weeks each price is below the product mean. Since these durations are dependend on length of the sample due to truncation, I restrict the analysis to the three longer comparable periods: the first and last 30 weeks of the 1990 sample (notice they overlap), and the 30 weeks of the 1992 sample.

These averages, for each product/store are reported in Table A4. Table 8 reports the store averages, as well as overall averages for each of the three periods. 


\section{Table 8}

Duration of Real Prices

\begin{tabular}{|l|c|c|c|c|c|c|c|}
\hline Period & $\% \pi_{t .}$ & Average & Store 1 & Store 2 & Store 3 & Store 4 & Store 5 \\
\hline 92 & 0.29 & 4.780 & 4.96 & 4.33 & 4.93 & 3.83 & 6.05 \\
$90 \mathrm{~B}$ & 1.15 & 2.265 & 2.36 & 3.06 & 2.26 & 1.74 & 1.91 \\
$90 \mathrm{~A}$ & 4.87 & 1.069 & 1.12 & 1.06 & 1.09 & 1.08 & 1 \\
\hline
\end{tabular}

The durability of real prices is decreasing in inflation. For instance, if you found a good price (below average), it is likely to last for about 5 weeks if you are in the low-inflation regime, while it will last for just about a week if you are in the high-inflation regime. ${ }^{15}$ This could have important costs as emphasized in the search-theoretic literature.

It is worth noting that, as explained below, part of the variability in low inflation times comes from the presence of mark-down sales. It is likely that these sales (1) represent a benefit to consumers and (2) are advertised in such a way that price information (in low-inflation times) is even better than reflected by these numbers.

\subsection{Mark-down sales.}

There is an old (vague) theme going back to Okun (1975 and 1981) and Carlton (1982): "inflation has Industrial Organization effects". High inflation introduces several distortions in the way firms conduct business (see the accounts in Heymann and Leijonhulfvud 1993 and references there). One of the most noticeable effects of poststabilization price stability in a country like Argentina, is the appearance of mark-down sales, catalogs, price advertising, and credit plans

15 Notice that the trumcation of the series is likely to bias downward the estimates of duration particularly for periods of longer durations (lower inflation). So that true durations will likely be longer than $\bar{j}$ weeks in the low-inflation regime. 


\section{Mariano Tommasi}

for the purchase of consumer durables (De Gregorio, Guidotti and Vegh, 1993). Practices that are taken for granted in countries like the U.S. or Canada, are a "luxury" of low-inflation times in Argentina. In this section, I provide some preliminary evidence on one of those effects.

The sample we use states when the reported quotation is claimed to be "on sale". As a check, I verified that in almost all of the cases (more than $90 \%$ of the time) the reported prices represented the minimum prices in their cross-sections and also nominal price decreases from their previous level.

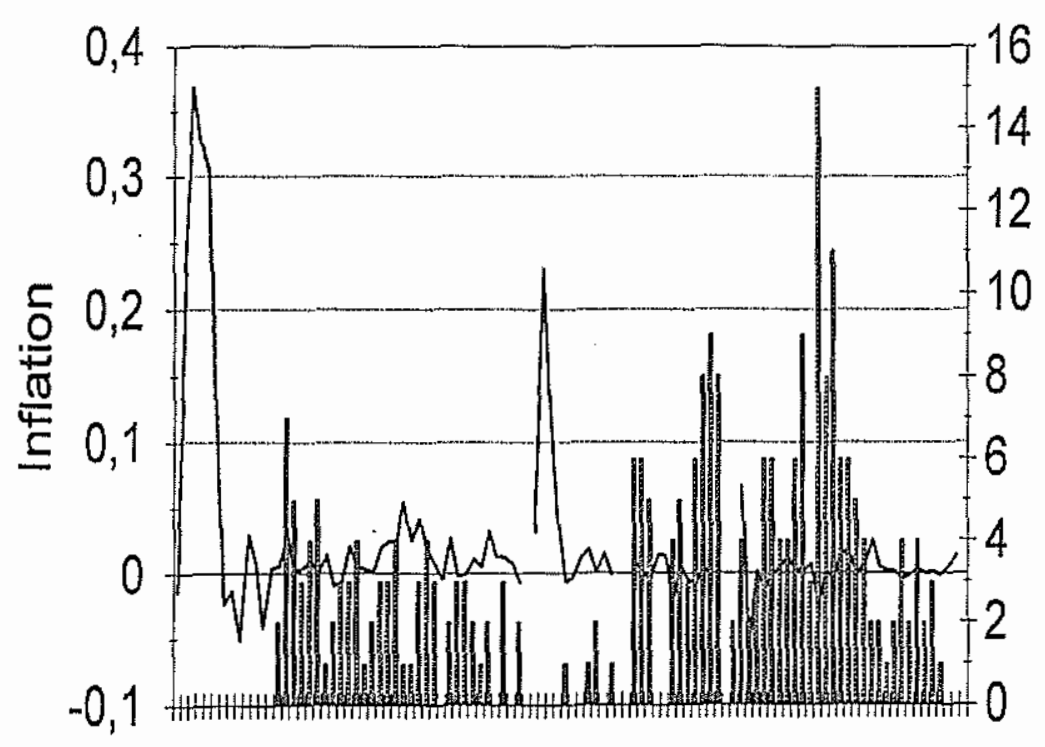

Weekly inflation 畨 Sales

Figure 2: Mark-down sales 
Figure 2 shows the number of sales, together with the weekly inflation rate for the sample. There are no sales during high-inflation episodes and they reappear with "stability". Possible explanations are that: (1) announcing $P_{i, j}$ provides little information if $P$ is unknown, and (2) it is very hard to compromise the maintenance of a nominal price for a long enough period to make a "sale" feasible. ${ }^{16}$

Insofar as the practice of mark-downs is welfare-improving for buyers (and sellers), we have an additional instance where inflation alters the transaction technology and hence diminishes welfare.

\section{Conclusion.}

Paul Krugman has argued that economics has a dirty little secret: We don't know why inflation is costly. This paper provides microeconomic evidence that sheds some light on the mechanisms by which real world inflations affect the heart of market economies: the price system. The evidence suggests that the informational content of real prices diminishes with inflation. Recent (and old) literature argues that the instability of real prices has efficiency costs.

This work needs to be extended in several directions. First, we did not attempt here any explanation of the findings. More theoretical (and more theoretically-grounded empirical) work is needed. Also, our sample is relatively small and un-representative. Broader coverage and similar studies with data from other countries - with different inflationary experiences - are necessary.

Finally, firm and market level studies of the impact of inflation in the organization of markets are badly needed.

Submetido em Agosto de 1996. Revisado em Novembro de 1996.

16 I an indebted to a referee of this Review for pointing ont that a third posssiljility is that at high inflation, the $(S, s)$ band widens in snch a way that customers with low cost of search can be "oflered low prices" without official mark-downs. 


\section{References}

Akerlof, George \& J. Yellen. 1985. "A near-rational model of the business cycle, with wage and price inertia." Quarterly Journal of Economics 100: 823-838.

Ball, Laurence \& S. Cecchetti. 1990. "Inflation and uncertainty at short and long horizons." Brookings Papers Econ. Activity 215-245.

Ball, Laurence \& D. Romer. 1992. "Inflation and the informativeness of prices." NBER, Working Paper 4267.

Benabou, Roland. 1993. "Search market equilibrium, bilateral heterogeneity, and repeat purchases." Journal of Economic Theory 60: $140-158$.

Blanchard, Olivier. 1990. "Why does money affect output? A survey." In Friedman and Hahn (eds), Handbook of Monetary Economics, vol. 2. Elsevier Science Publishers, 779-835.

Blanchard, Olivier \& N. Kiyotaki. 1987. "Monopolistic competition and the effects of aggregate demand." American Economic Review 77: 647-666.

Bonomo, Marco. 1994. "Optimal two-sided and suboptimal onesided pricing rules." PUC/RJ, Working Paper 313.

Bonomo, Marco \& S. Najberg. 1993. "Inflation and timely recall." In Anais do XV Encontro Brasileiro de Econometria.

Caballero, Ricardo \& E. Engel. 1991. "Dynamic $(S, s)$ economies." Econometrica LXI: 1659-1686.

Caplin, Andrew. 1993. "Individual inertia and aggregate dynamics." In Sheshinski and Weiss (eds), Optimal Pricing, Inflation and Cost of Price Adjustment. MIT Press.

Caplin, Andrew \& J. Leahy. 1991. "State dependent pricing and the dynamics of money and output." Quarterly Journal of Economics CVI: 683-708. 
Caplin, Andrew \& Eytan Sheshinski. 1987. "Optimality of $(S, s)$ pricing policies". Mimeo.

Caplin, Andrew \& D. Spulber. 1987. "Menu costs and the neutrality of money." Quarterly Journal of Economics 102: 703-725.

Carlton, Dennis. 1982. "The disruptive effect of inflation on the organization of markets." In R. Hall (ed), Inflation. Chicago: University of Chicago Press.

Cecchitti, Stephen. 1985. "Staggered contracts and the frequency of price adjustment." Quarterly Journal of Economics 100: 935959.

Cecchitti, Stephen. 1986. "The frequency of price adjustment: A study of the newsstand price of magazines." Journal of Econometrics 31: 255-274.

Cukierman, Alex. 1983. "Relative price variability and inflation: A survey and further results." Carnegie Rochester Series on Public Policy. Autumn: 103-158.

De Gregorio, J.; P. Guidotti \& C. Vegh. 1993. "Inflation stabilization and the consumption of durables." Mimeo, Research Department IMF.

Evans, Martin. 1991. "Discovering the link between inflation rates and inflation uncertainty." Journal of Money, Credit and Banking 23: 169-184.

Evans, Martin \& P. Wachtel. 1993. "Inflation regimes and the sources of inflation uncertainty." Journal of Money, Credit and Banking 25: 475-511.

Ferreira, Sergio. 1995. Inflação, Regras de Ajuste e Busca Sequencial: Uma Análise sob a Ótica da Dispersão de Preços Relativos. BNDES.

Fischer, Stanley. 1981. "Relative shocks, relative price variability, and inflation." Brookings Papers Econ. Activity 2: 381-431. 


\section{Mariano Tommasi}

Fischer, Stanley. 1986. Indexing, Inflation and Economic Policy. Cambridge: MIT Press.

Fisher, Tim \& J. Konieczny. 1993. "Inflation and price adjustment: A study of canadian newspaper prices." Mimeo, Wilfrid Laurier University.

Fishman, Arthur \& R. Rob. 1991. "The durability of information, market efficiency and the size of firms; search with repeated transactions." Mimeo, University of Pennsylvania.

Flinn, C. \& Heckman, J. 1982. "New methods for analyzing structural models of labor force dynamics." Journal of Econometrics 18: $115-168$.

Friedman, Milton. 1977. "Nobel lecture: Inflation and unemployment." Journal of Political Economy 85: 451-472.

Golob, John. 1993. "Inflation, inflation uncertainty and relative price variability: A survey." Federal Reserve Bank of Kansas City, Research Working Paper 93-15.

Hartman, Richard. 1991. "Relative price variability and inflation." Journal of Money, Credit and Banking 23: 185-205.

Heiner, Ronald. 1983. "The origin of predictable behavior." American Economic Review 83: 560-595.

Heymann, Daniel \& A. Leijonhulfvud. 1993. High inflation. Oxford University Press. Forthcoming.

Huizinga, John. 1993. "Inflation uncertainty, relative price uncertainty, and investment in U.S. manufacturing." Journal of Money, Credit and Banking 25: 521-549.

Lach, Saul \& Daniel Tsiddon. 1990. "The behavior of prices and inflation: An empirical analysis of disaggregated data." The Hebrew University, Working Paper 224.

Lach, Saul \& Daniel Tsiddon. 1992. "The behavior of prices and inflation: An empirical analysis of disaggregated price data." Journal of Political Economy 100: 349-389. 
Leijonhulvfud, Axel. 1991. "High inflations and contemporary monetary theory." Economic Notes by Monte dei Paschi di Siena 21: 211-224.

Mankiw, N. Gregory. 1985. "Small menu costs and large business cycles: A macroeconomic model of monopoly." Quarterly Journal of Economics 100: 529-539.

Marquez, Jaime \& D. Vining. 1984. "Inflation and relative price behavior: A survey of the literature." In M. Ballobon (ed), Economic Perspectives: An Annual Survey of Economics, vol. 3. New York: Harwood Academic Publishers, 1-52.

McMillan, John \& Peter Morgan. 1988. "Price dispersion, price flexibility and repeated purchasing." Canadian Journal of Economics 21: 883-902.

Okun, Arthur. 1975. "Inflation: Its mechanics and welfare costs." Brookings Papers on Economic Activity 2: 351-399.

Okin, Arthur. 1981. Prices and Quantities. Washington D.C.: The Brookings Institution.

Palerm, Angel. 1990. "Price formation and relative price variability in an inflationary environment: Mexico, 1940-1984." Ph.D. Dissertation. University of California Los Angeles.

Parkin, Michael. 1986. "The output-inflation trade-off when prices are costly to change." Journal of Political Economy 94: 200-224.

Reagan, Patricia \& Rene Stultz. 1993. "Contracting costs, inflation and relative price variability." Journal of Money, Credit and Banking 25: 585-601.

Scarf, Herbert. 1959. "The optimality of $(S, s)$ policies in the dynamic inventory problem." In Arrow, K.; S. Carlin and P. Suppes (eds), Mathematical Methods in the Social Sciences. Stanford University Press.

Sheshinski, Eytan \& Yoram, Weiss. 1977. "Inflation and costs of price adjustment." Review of Economic Studies 44: 287-304. 


\section{Mariano Tommasi}

Sheshinski, Eytan \& Yoram, Weiss. 1983. "Optimum pricing policy under stochastic inflation." Review of Economic Studies 50: 513-529.

Tommasi, Mariano. 1993. "Inflation and relative prices: Evidence from Argentina." IN Sheshinski and Weiss (eds), Optimal Pricing, Inflation and the Cost of Price Adjustment. MIT Press.

Tommasi, Mariano. 1994. "The consequences of price instability on search markets: Towards understanding the effects of inflation." American Economic Review 84: 1385-1396.

Ungar, M. \& Ben-Zion Zilberfarb. 1993. "Inflation and its unpredictability - Theory and empirical evidence." Journal of Money, Credit and Banking 25: 709-720.

Weiss, Yoram. 1993. "Inflation and price adjustment: A survey of findings from micro-data." In Sheshinski and Weiss (eds), Optimal Pricing, Inflation and the Cost of Price Adjustment. MIT Press.

Winer, Russell. 1986. "A reference price model of brand choice for frequently purchased products." Journal of Consumer Research 13: 250-256. 
Inflation and the informativeness of prices

Table AI

Correlation of Real Prices

\begin{tabular}{|c|c|c|c|c|c|c|c|}
\hline GOOD & PERIOD & \multicolumn{6}{|c|}{ STORES } \\
\hline \multirow[t]{18}{*}{ Butter } & \multirow[t]{3}{*}{$90-1$} & Coef. & -0.155 & 0.53 & 0.42 & 0.14 & 0.18 \\
\hline & & $\mathrm{t}$ & -0.56 & 2.2 & 1.6 & 0.51 & 0.65 \\
\hline & & SER & 0.1 & 0.099 & 0.05 & 0.078 & 0.084 \\
\hline & \multirow[t]{3}{*}{$90-2$} & Coef. & 0.6 & -0.06 & 0.77 & 0.96 & 0.27 \\
\hline & & $t$ & 2.6 & -0.21 & 5.2 & 11.5 & 1.2 \\
\hline & & SER & & 0.035 & 0.032 & 0.02 & 0.03 \\
\hline & \multirow[t]{3}{*}{$90-3$} & Coef. & 0.51 & 0.13 & 0.37 & 0.51 & 0.3 \\
\hline & & $\mathrm{l}$ & 2.6 & 0.52 & 1.5 & 3.0 & 1.2 \\
\hline & & SER & 0.03 & 0.029 & 0.04 & 0.03 & 0.04 \\
\hline & \multirow[t]{3}{*}{$91-1$} & Coef. & 0.18 & 0.77 & 0.6 & -0.08 & 0.83 \\
\hline & & $\mathrm{t}$ & 0.6 & 3.7 & 2.4 & -0.25 & 4.4 \\
\hline & & SER & 0.034 & 0.06 & 0.06 & 0.055 & 0.024 \\
\hline & \multirow[t]{3}{*}{$91-2$} & Coef. & 1.01 & 1.0 & 1.0 & 0.86 & 0.94 \\
\hline & & 1 & 12.2 & 102.0 & 20.0 & 7.0 & 12.0 \\
\hline & & SER & 0.003 & 0.002 & 0.01 & 0.01 & 0.02 \\
\hline & \multirow[t]{3}{*}{92} & Coef. & 0.76 & 1.0 & 0.83 & 0.83 & 0.86 \\
\hline & & $\mathrm{t}$ & 6.5 & 31.5 & 12.2 & 7.9 & 9.1 \\
\hline & & SER & 0.023 & 0.017 & 0.01 & 0.01 & 0.03 \\
\hline \multirow{18}{*}{ Colfiee } & \multirow{3}{*}{$90-1$} & & & & & 004 & \\
\hline & & coci. & 0.42 & $\begin{array}{l}0.1 \\
35\end{array}$ & $\begin{array}{r}0.4 J \\
18\end{array}$ & $\begin{array}{r}0.94 \\
8.1\end{array}$ & $\begin{array}{r}0.85 \\
57\end{array}$ \\
\hline & & SER & 01 & 0.11 & 0.13 & 0.048 & 0.07 \\
\hline & \multirow{3}{*}{$90-2$} & Coef. & 0.22 & 0.69 & 0.75 & 0.76 & 0.5 \\
\hline & & 1 & 0.88 & 3.5 & 5.2 & 5.7 & 2.25 \\
\hline & & SER & 0.067 & 0.057 & 0.04 & 0.036 & 0.03 \\
\hline & \multirow[t]{3}{*}{$90-3$} & Coef. & 0.54 & 0.55 & 0.86 & 0.9 & 0.86 \\
\hline & & 1 & 2.5 & 2.2 & 5.9 & 9.6 & 4.8 \\
\hline & & SER & 0.056 & 0.089 & 0.058 & 0.76 & 0.91 \\
\hline & \multirow[t]{3}{*}{$91-1$} & Coef. & 0.5 & 0.67 & 0.75 & 0.76 & 0.91 \\
\hline & & $t$ & 1.7 & 2.6 & 3.2 & 3.2 & 7.5 \\
\hline & & SER & 0.05 & 0.07 & 0.06 & 0.04 & 0.019 \\
\hline & \multirow[t]{3}{*}{$91-2$} & Coef. & 0.8 & 0.8 & 0.97 & 1.05 & 0.71 \\
\hline & & $\mathrm{t}$ & 4.3 & 3.9 & 25.0 & 15.9 & 4.4 \\
\hline & & SER & 0.06 & 0.05 & 0.015 & 0.03 & 0.06 \\
\hline & \multirow[t]{3}{*}{92} & Coef. & 0.58 & 0.8 & 0.8 & 0.7 & 0.7 \\
\hline & & 1 & 4.2 & 9.0 & 8.7 & 5.1 & 5.7 \\
\hline & & SER & 0.03 & 0.02 & 0.02 & 0.05 & 0.034 \\
\hline
\end{tabular}


Mariano Tommasi

(Cont. Table Al)

\begin{tabular}{|c|c|c|c|c|c|c|c|}
\hline \multirow{4}{*}{$\begin{array}{c}\text { GOOD } \\
\text { Flour }\end{array}$} & \multirow{4}{*}{$\begin{array}{c}\text { PERIOD } \\
90-1\end{array}$} & \multicolumn{6}{|c|}{ STORES } \\
\hline & & Coef. & 0.53 & 0.02 & 0.5 & 0.39 & 0.31 \\
\hline & & $t$ & 2.3 & 0.08 & 2.0 & 1.55 & 1.4 \\
\hline & & SER & 0.1 & 0.2 & 0.12 & 0.11 & 1.075 \\
\hline & $90-2$ & Coef: & 0.39 & 0.3 & 0.69 & 0.43 & 0.77 \\
\hline & & $\mathrm{t}$ & 1.5 & 1.8 & 3.9 & 3.0 & 4.9 \\
\hline & & SER & 0.065 & 0.08 & 0.04 & 0.04 & 0.05 \\
\hline & $90-3$ & Coef. & 0.38 & 0.19 & 0.77 & 0.87 & 0.54 \\
\hline & & $\mathrm{t}$ & 1.8 & 0.75 & 5.3 & 5.9 & 2.4 \\
\hline & & SER & 0.05 & 0.06 & 0.06 & 0.058 & 0.096 \\
\hline & $91-1$ & Coef. & 0.38 & 0.63 & 0.51 & 0.7 & 0.46 \\
\hline & & 1 & 1.52 & 2.2 & 1.6 & 3.0 & 1.6 \\
\hline & & SER & 0.037 & 0.063 & 0.065 & 0.066 & 0.097 \\
\hline & $91-2$ & Coef. & 0.74 & 0.73 & 0.02 & 0.8 & 0.84 \\
\hline & & $t$ & 3.4 & 3.4 & 0.07 & 4.1 & 4.4 \\
\hline & & SER & 0.075 & 0.06 & 0.08 & 0.06 & 0.06 \\
\hline & 92 & Coef. & 0.5 & 0.7 & 0.5 & 0.8 & 0.9 \\
\hline & & 1 & 3.8 & 4.3 & 3.1 & 7.9 & 10.7 \\
\hline & & SER & 0.02 & 0.02 & 0.03 & 0.03 & 0.03 \\
\hline L aundry & $90-1$ & Coef & -013 & 076 & 0.64 & 029 & 0.65 \\
\hline Detergent & & 1 & -0.47 & 3.9 & 3.5 & 1.14 & 3.2 \\
\hline & & SER & 0.064 & 0.08 & 0.06 & 0.02 & 0.087 \\
\hline & $90-2$ & Coef. & 0.86 & 1.07 & 0.89 & & 0.9 \\
\hline & & $\mathrm{t}$ & 6.15 & 8.2 & 7.5 & & 7.3 \\
\hline & & SER & 0.015 & 0.9022 & 0.05 & & 0.015 \\
\hline & $90-3$ & Coef. & 0.59 & 0.68 & 0.96 & & 0.8 \\
\hline & & $t$ & 2.8 & 2.7 & 10.9 & & 4.7 \\
\hline & & SER & 0.05 & 0.06 & 0.023 & & 0.05 \\
\hline & $91-1$ & Coef. & 0.49 & -0.27 & $\begin{array}{l}0.78 \\
\end{array}$ & 0.7 & 0.49 \\
\hline & & $t$ & 1.64 & -0.24 & 3.88 & 3.2 & 2.3 \\
\hline & & SER & 0.4 & 1.11 & 0.34 & 0.4 & 0.4 \\
\hline & $91-2$ & Coef. & 1.04 & 0.97 & 1.01 & 0.5 & 0.6 \\
\hline & & $t$ & 16.4 & 9.8 & 17.8 & 1.83 & 2.4 \\
\hline & & SER & 0.003 & 0.02 & 0.02 & 0.05 & 0.02 \\
\hline & 92 & Coef. & 0.9 & 1.04 & 0.88 & 0.76 & 0.81 \\
\hline & & $\mathrm{t}$ & 12.7 & 24.5 & 9.9 & 6.4 & 6.4 \\
\hline & & SER & 0.02 & 0.01 & 0.04 & 0.02 & 0.04 \\
\hline
\end{tabular}


Inflation and the informativeness of prices

(Cont. Table Al)

\begin{tabular}{|c|c|c|c|c|c|c|c|}
\hline GOOD & PERIOD & \multicolumn{6}{|c|}{ STORES } \\
\hline \multirow[t]{3}{*}{ Oil } & \multirow[t]{3}{*}{$90-1$} & Coel". & 0.4 & 0.5 & 0.16 & 0.3 & 0.28 \\
\hline & & 1 & 1.75 & 2.2 & 0.66 & 1.2 & 1.1 \\
\hline & & SER & 0.09 & 0.096 & 0.05 & 0.055 & 0.06 \\
\hline & $90-2$ & Coef. & 0.79 & 0.5 & -0.15 & 0.46 & 0.75 \\
\hline & & 1 & 3.1 & 2.4 & -0.6 & 1.9 & 4.5 \\
\hline & & SER & 0.03 & 0.04 & 0.024 & 0.06 & 0.05 \\
\hline & $90-3$ & Coel. & 0.3 & 0.12 & 0.65 & 0.85 & 0.83 \\
\hline & & 1 & 2.1 & 0.6 & 3.4 & 6.6 & 5.5 \\
\hline & & SER & 0.017 & 0.045 & 0.037 & 0.03 & 0.03 \\
\hline & $91-1$ & Coel: & 0.58 & 0.67 & 0.5 & 0.79 & 0.93 \\
\hline & & 1 & 2.24 & 3.5 & 0.26 & 4.2 & 8.3 \\
\hline & & SER & 0.58 & 0.025 & 0.04 & 0.05 & 0.02 \\
\hline & $91-2$ & Coef: & 0.13 & 0.7 & 0.73 & 0.9 & 0.5 \\
\hline & & 1 & 0.53 & 3.6 & 3.4 & 9.7 & 1.8 \\
\hline & & SER & 0.05 & 0.04 & 0.06 & 0.03 & 0.02 \\
\hline & 92 & Coel. & 0.8 & 0.88 & 0.88 & 0.76 & 0.79 \\
\hline & & $t$ & 7.2 & 9.4 & 9.4 & 7.4 & 6.9 \\
\hline & & SER & 0.04 & 0.03 & 0.03 & 0.03 & 0.05 \\
\hline & & & & & & & \\
\hline Peals & $90-1$ & Coel". & 0.67 & 0.62 & 0.63 & 0.54 & 0.37 \\
\hline & & 1 & 3.05 & 2.8 & 2.8 & 2.3 & 1.5 \\
\hline & & SER & 0.095 & 0.16 & 0.12 & 0.14 & 0.16 \\
\hline & $90-2$ & Coel:. & 0.77 & 0.97 & 0.96 & 0.66 & 0.93 \\
\hline & & $\mathrm{t}$ & 5.5 & 13.1 & 9.9 & 3.3 & 9.4 \\
\hline & & SER & 0.05 & 0.039 & 0.054 & 0.08 & 0.05 \\
\hline & $90-3$ & Coel. & -0.4 & 1.0 & 0.97 & 0.02 & 1.0 \\
\hline & & 1 & -1.5 & 12.3 & 11.3 & 0.09 & 13.4 \\
\hline & & SER & 0.038 & 0.09 & 0.066 & 0.044 & 0.06 \\
\hline & $91-1$ & Coel: & 0.087 & 0.75 & 0.9 & 0.58 & 0.68 \\
\hline & & $\mathrm{t}$ & 0.34 & 4.18 & 9.44 & 1.98 & 2.87 \\
\hline & & SER & 0.29 & 0.33 & 0.37 & 0.29 & 0.29 \\
\hline & $91-2$ & Coefi. & 0.76 & 0.7 & 1.02 & 0.5 & 0.76 \\
\hline & & 1 & 3.6 & 2.8 & 9.4 & 2.0 & 3.6 \\
\hline & & SER & 0.1 & 0.1 & 0.1 & 0.02 & 0.02 \\
\hline & 92 & Coef. & 0.9 & 0.88 & 0.94 & 0.93 & 0.9 \\
\hline & & $t$ & 8.7 & 10.2 & 14.6 & 11.7 & 8.7 \\
\hline & & SER & 0.06 & 0.05 & 0.04 & 0.045 & 0.057 \\
\hline
\end{tabular}


Mariano Tommasi

(Cont. Table Al)

\begin{tabular}{|c|c|c|c|c|c|c|c|}
\hline GOOD & PERIOD & & & STC & & & \\
\hline Rice & $90-1$ & Coef. & 0.34 & 0.878 & $1 \mathrm{E}-05$ & 0.01 & \\
\hline & & $t$ & 1.3 & 0.26 & 1.5 & 0.0003 & 0.04 \\
\hline & & SER & 0.15 & 0.13 & 0.079 & 0.07 & 0.09 \\
\hline & $90-2$ & Cocf. & 0.9 & 0.99 & 0.82 & 0.98 & 1.0 \\
\hline & & $\mathrm{t}$ & 7.8 & 11.8 & 6.8 & 16.7 & 11.6 \\
\hline & & SER & 0.023 & 0.025 & 0.018 & 0.015 & 0.025 \\
\hline & $90-3$ & Coef. & 0.3 & 0.83 & 0.71 & 0.83 & 0.78 \\
\hline & & 1 & 1.2 & 5.6 & 3.8 & 5.9 & 4.9 \\
\hline & & SER & 0.58 & 0.077 & 0.09 & 0.05 & 0.087 \\
\hline & $91-1$ & Coef. & 0.6 & 0.54 & 0.71 & 0.53 & 0.87 \\
\hline & & 1 & 2.4 & 2.0 & 2.8 & 1.9 & 5.2 \\
\hline & & SER & 0.036 & 0.075 & 0.046 & 0.077 & 0.05 \\
\hline & $91-2$ & Coef. & 0.57 & 0.66 & 0.78 & 0.87 & 0.8 \\
\hline & & 1 & 2.2 & 2.6 & 3.7 & 5.7 & 5.0 \\
\hline & & SER & 0.02 & 0.02 & 0.03 & 0.046 & 0.036 \\
\hline & 92 & Coef. & 0.64 & 0.9 & 0.91 & 0.65 & 0.93 \\
\hline & & 1 & 4.4 & 11.8 & 10.6 & 5.0 & 12.1 \\
\hline & & SER & 0.03 & 0.01 & 0.015 & 0.03 & 0.03 \\
\hline & & & & & & & \\
\hline Tea & $90-1$ & Cocf. & 0.26 & 0.37 & -0.06 & -0.007 & 0.12 \\
\hline & & 1 & 0.98 & 1.5 & -0.23 & -0.03 & 0.42 \\
\hline & & SER & 0.116 & 0.21 & 0.13 & 0.16 & 0.13 \\
\hline & $90-2$ & Coef. & 0.31 & 0.96 & 0.7 & 0.52 & 0.87 \\
\hline & & $t$ & 0.92 & 6.7 & 3.1 & 1.6 & 6.2 \\
\hline & & SER & 0.35 & 0.053 & 0.08 & 0.11 & 0.06 \\
\hline & $90-3$ & Coef. & 0.69 & 0.94 & 0.69 & 0.8 & 0.68 \\
\hline & & $\mathrm{t}$ & 3.9 & 7.4 & 4.8 & 12.8 & 4.3 \\
\hline & & SER & 0.04 & 0.026 & 0.05 & 0.04 & 0.057 \\
\hline & $91-1$ & Coef. & 0.55 & 0.81 & 0.42 & 0.34 & 0.5 \\
\hline & & $t$ & 2.5 & 4.2 & 1.4 & 1.1 & 1.8 \\
\hline & & SER & 0.03 & 0.05 & 0.1 & 0.07 & 0.07 \\
\hline & $91-2$ & Coef. & 0.97 & 0.83 & 0.98 & 1.0 & 0.96 \\
\hline & & $\mathrm{t}$ & 63.4 & 16.4 & 35.6 & 41.9 & 20.7 \\
\hline & & SER & 0.002 & 0.002 & 0.007 & 0.005 & 0.007 \\
\hline & 92 & Coef. & 0.09 & 0.93 & 0.9 & 0.9 & 0.8 \\
\hline & & $\mathrm{t}$ & 11.9 & 13.9 & 10.7 & 13.7 & 6.9 \\
\hline & & SER & 0.017 & 0.018 & 0.04 & 0.02 & 0.05 \\
\hline
\end{tabular}


Inflation and the informativeness of prices

(Cont. Table AI)

\begin{tabular}{|c|c|c|c|c|c|c|c|}
\hline GOOD & PERIOD & \multicolumn{6}{|c|}{ STORES } \\
\hline \multirow[t]{18}{*}{ Tomato } & \multirow[t]{3}{*}{$90-1$} & Coef. & -0.14 & 0.001 & -0.33 & -0.25 & 0.19 \\
\hline & & 1 & -0.53 & 0.003 & -1.3 & -0.92 & 0.72 \\
\hline & & SER & 0.096 & 0.14 & 0.08 & 0.12 & 0.11 \\
\hline & \multirow[t]{3}{*}{$90-2$} & Coefl. & 0.7 & 0.76 & 0.68 & 0.58 & 0.7 \\
\hline & & 1 & 2.8 & 4.1 & 1.86 & 2.8 & 3.8 \\
\hline & & SER & 0.063 & 0.06 & 0.06 & 0.055 & 0.056 \\
\hline & \multirow[t]{3}{*}{$90-3$} & Coef. & 0.79 & 0.89 & 0.67 & 0.74 & 0.94 \\
\hline & & $\mathrm{t}$ & 4.6 & 5.5 & 3.9 & 4.1 & 8.7 \\
\hline & & SER & 0.08 & 0.12 & 0.97 & 0.08 & 0.05 \\
\hline & \multirow[t]{3}{*}{$91-1$} & Cocf. & 0.7 & 0.55 & 0.8 & 0.72 & 0.67 \\
\hline & & $\mathrm{t}$ & 4.7 & 2.6 & 6.6 & 3.3 & 3.1 \\
\hline & & SER & 0.04 & 0.09 & 0.08 & 0.06 & 0.08 \\
\hline & \multirow[t]{3}{*}{$91-2$} & Coef. & 0.18 & 0.56 & 0.9 & 0.87 & 0.65 \\
\hline & & $t$ & 0.6 & 1.96 & 7.3 & 3.4 & 2.5 \\
\hline & & SER & 0.09 & 0.05 & 0.05 & 0.05 & 0.05 \\
\hline & \multirow[t]{3}{*}{92} & Coef. & 0.44 & 0.5 & 0.4 & 0.23 & -0.01 \\
\hline & & $\mathrm{t}$ & 2.6 & 3.0 & 2.5 & 1.1 & -0.06 \\
\hline & & SER & 0.06 & 0.07 & 0.05 & 0.055 & 0.39 \\
\hline \multirow{19}{*}{ Yerba } & \multirow{4}{*}{$90-1$} & & & & & & \\
\hline & & Cocf. & 0.57 & 0.33 & 0.39 & 0.8 & 0.51 \\
\hline & & $\mathrm{t}$ & 2.5 & 1.25 & 1.5 & 4.9 & 2.13 \\
\hline & & SER & 0.068 & 0.11 & 0.04 & 0.044 & 0.09 \\
\hline & \multirow[t]{3}{*}{$90-2$} & Coef. & 0.74 & 0.39 & 0.83 & $\begin{array}{ll}0.84 \\
\end{array}$ & 0.83 \\
\hline & & $\mathrm{t}$ & 4.26 & 1.4 & 3.7 & 5.3 & 5.4 \\
\hline & & SER & 0.03 & 0.05 & 0.04 & 0.039 & 0.035 \\
\hline & \multirow[t]{3}{*}{$90-3$} & Coef. & 0.63 & 0.82 & 0.78 & 0.87 & 0.84 \\
\hline & & $t$ & 3.0 & 5.6 & 5.7 & 7.9 & 7.0 \\
\hline & & SER & 0.04 & 0.044 & 0.03 & 0.028 & 0.023 \\
\hline & \multirow[t]{3}{*}{$91-1$} & Coef. & 0.7 & 0.8 & 0.63 & 0.73 & 0.58 \\
\hline & & $\mathrm{t}$ & 2.8 & 5.0 & 2.6 & 2.9 & 2.2 \\
\hline & & SER & 0.04 & 0.05 & 0.07 & 0.06 & 0.06 \\
\hline & \multirow[t]{3}{*}{$91-2$} & Coef. & 0.9 & 0.9 & 0.91 & 0.94 & 0.64 \\
\hline & & 1 & 14.9 & 10.0 & 6.9 & 14.4 & 6.5 \\
\hline & & SER & 0.01 & 0.01 & 0.04 & 0.012 & 0.026 \\
\hline & \multirow[t]{3}{*}{92} & Coef. & 0.67 & 0.39 & 0.72 & -0.2 & 0.45 \\
\hline & & $\mathrm{t}$ & 4.8 & 2.27 & 6.2 & -1.15 & 2.7 \\
\hline & & SER & 0.18 & 0.18 & 0.24 & 0.19 & 0.23 \\
\hline
\end{tabular}


Mariano Tommasi

Table A2

Correlation of Store Bundles

\begin{tabular}{|c|c|c|c|c|c|c|}
\hline PERIOD & \multicolumn{6}{|c|}{ STORES } \\
\hline $\begin{array}{c}1990 \\
15 \text { weeks } \\
\text { Feb-May }\end{array}$ & $\begin{array}{c}\text { RO } \\
\text { MSE }\end{array}$ & $\begin{array}{r}0.58 \\
0.044\end{array}$ & $\begin{array}{r}0.61 \\
0.046\end{array}$ & $\begin{array}{r}0.41 \\
0.041\end{array}$ & $\begin{array}{r}0.89 \\
0.031\end{array}$ & $\begin{array}{r}0.77 \\
0.044\end{array}$ \\
\hline $\begin{array}{c}1990 \\
15 \text { weeks } \\
\text { May-Aug }\end{array}$ & $\begin{array}{c}\text { RO } \\
\text { MSE }\end{array}$ & $\begin{array}{r}0.49 \\
0.027\end{array}$ & $\begin{array}{r}0.86 \\
0.022\end{array}$ & $\begin{array}{r}0.96 \\
0.021\end{array}$ & $\begin{array}{r}0.97 \\
0.015\end{array}$ & $\begin{array}{r}0.91 \\
0.016\end{array}$ \\
\hline $\begin{array}{c}1990 \\
15 \text { weeks } \\
\text { Aug-Dec }\end{array}$ & $\begin{array}{l}\text { RO } \\
\text { MSE }\end{array}$ & $\begin{array}{r}0.05 \\
0.023\end{array}$ & $\begin{array}{r}0.97 \\
0.029\end{array}$ & $\begin{array}{r}0.93 \\
0.024\end{array}$ & $\begin{array}{r}0.94 \\
0.017\end{array}$ & $\begin{array}{r}1.01 \\
0.014\end{array}$ \\
\hline $\begin{array}{c}1991 \\
15 \text { weeks } \\
\text { Jan-Apr }\end{array}$ & $\begin{array}{c}\text { RO } \\
\text { MSE }\end{array}$ & $\begin{array}{r}0.46 \\
0.018\end{array}$ & $\begin{array}{r}0.96 \\
0.014\end{array}$ & $\begin{array}{r}0.77 \\
0.048\end{array}$ & $\begin{array}{r}0.83 \\
0.039\end{array}$ & $\begin{array}{l}0.94 \\
0.02\end{array}$ \\
\hline $\begin{array}{c}1991 \\
12 \text { weeks } \\
\text { Sept-Dec }\end{array}$ & $\begin{array}{c}\text { RO } \\
\text { MSE }\end{array}$ & $\begin{array}{r}0.67 \\
0.018\end{array}$ & $\begin{array}{r}0.82 \\
0.016\end{array}$ & $\begin{array}{r}0.97 \\
0.014\end{array}$ & $\begin{array}{r}0.97 \\
0.019\end{array}$ & $\begin{array}{r}0.79 \\
0.017\end{array}$ \\
\hline $\begin{array}{c}1992 \\
30 \text { weeks } \\
\text { Apr-Nov }\end{array}$ & $\begin{array}{c}\text { RO } \\
\text { MSE }\end{array}$ & $\begin{array}{r}0.87 \\
0.016\end{array}$ & $\begin{array}{r}0.96 \\
0.011\end{array}$ & $\begin{array}{r}0.83 \\
0.013\end{array}$ & & $\begin{array}{r}0.84 \\
0.022\end{array}$ \\
\hline
\end{tabular}


Inflation and the informativeness of prices

Table A3

Excess Variability of Relative Prices

\begin{tabular}{|l|c|c|c|c|c|c|}
\hline \multicolumn{7}{|c|}{ BUTTER $\left(\mathrm{CV}_{\text {ij }}\right)$} \\
\hline PERIOD & Storc 1 & Storc 2 & Storc 3 & Storc 4 & Storc 5 & CVI \\
\hline 90I & 0.118 & 0.125 & 0.086 & 0.126 & 0.114 & 0.084 \\
\hline $90 \mathrm{II}$ & 0.060 & 0.079 & 0.093 & 0.070 & 0.072 & 0.070 \\
\hline $90 \mathrm{III}$ & 0.073 & 0.087 & 0.073 & 0.082 & 0.074 & 0.070 \\
\hline $91 \mathrm{I}$ & 0.069 & 0.062 & 0.083 & 0.074 & 0.065 & 0.058 \\
\hline $91 \mathrm{II}$ & 0.030 & 0.022 & 0.025 & 0.025 & 0.023 & 0.024 \\
\hline 92 & 0.018 & 0.027 & 0.026 & 0.034 & 0.033 & 0.019 \\
\hline
\end{tabular}

\begin{tabular}{|l|c|c|c|c|c|c|}
\hline \multicolumn{7}{|c|}{ COFFEE } \\
\hline PERIOD & Store 1 & Store 2 & Store 3 & Store 4 & Store 5 & CVI \\
\hline $90 \mathrm{I}$ & 0.099 & 0.152 & 0.127 & 0.127 & 0.091 & 0.092 \\
\hline $90 \mathrm{II}$ & 0.049 & 0.027 & 0.041 & 0.081 & 0.068 & 0.022 \\
\hline $90 \mathrm{III}$ & 0.022 & 0.046 & 0.060 & 0.070 & 0.095 & 0.021 \\
\hline $91 \mathrm{I}$ & 0.063 & 0.060 & 0.039 & 0.046 & 0.074 & 0.050 \\
\hline $91 \mathrm{II}$ & 0.036 & 0.015 & 0.052 & 0.078 & 0.042 & 0.025 \\
\hline 92 & 0.051 & 0.057 & 0.052 & 0.056 & 0.022 & 0.027 \\
\hline
\end{tabular}

\begin{tabular}{|l|c|c|c|c|c|c|}
\hline \multicolumn{7}{|c|}{ LAUNDRY DETERGENT } \\
\hline PERIOD & Store 1 & Storc 2 & Store 3 & Storc 4 & Store 5 & CVI \\
\hline $90 \mathrm{I}$ & 0.261 & 0.219 & 0.233 & 0.254 & 0.217 & 0.192 \\
\hline $90 \mathrm{II}$ & 0.081 & 0.083 & 0.082 & 0.122 & 0.068 & 0.076 \\
\hline $90 \mathrm{III}$ & 0.077 & 0.18 & 0.056 & 0.103 & 0.111 & 0.073 \\
\hline $91 \mathrm{I}$ & 0.063 & 0.048 & 0.044 & 0.019 & 0.073 & 0.027 \\
\hline $91 \mathrm{II}$ & 0.043 & 0.043 & 0.096 & 0.066 & 0.038 & 0.052 \\
\hline 92 & 0.051 & 0.078 & 0.021 & 0.027 & 0.016 & 0.024 \\
\hline
\end{tabular}


Mariano Tommasi

(Cont. Table A3)

\begin{tabular}{|l|c|c|c|c|c|c|}
\hline \multicolumn{7}{|c|}{ PEAS } \\
\hline PERIOD & Store 1 & Store 2 & Store 3 & Storc 4 & Storc 5 & CVI \\
\hline $90 \mathrm{I}$ & 0.114 & 0.224 & 0.163 & 0.104 & 0.160 & 0.078 \\
\hline $90 \mathrm{II}$ & 0.132 & 0.061 & 0.031 & 0.080 & 0.039 & 0.033 \\
\hline $90 \mathrm{III}$ & 0.041 & 0.038 & 0.063 & 0.061 & 0.088 & 0.039 \\
\hline $91 \mathrm{I}$ & 0.045 & 0.025 & 0.056 & 0.075 & 0.449 & 0.027 \\
\hline $91 \mathrm{II}$ & 0.019 & 0.043 & 0.027 & 0.124 & 0.076 & 0.036 \\
\hline 92 & 0.073 & 0.059 & 0.024 & 0.054 & 0.034 & 0.027 \\
\hline
\end{tabular}

TOMATO SAUCE

\begin{tabular}{|l|c|c|c|c|c|c|}
\hline PERIOD & Store 1 & Store 2 & Store 3 & Store 4 & Store 5 & CVI \\
\hline 90I & 0.122 & 0.116 & 0.092 & 0.097 & 0.149 & 0.055 \\
\hline $90 I I$ & 0.054 & 0.080 & 0.043 & 0.099 & 0.111 & 0.057 \\
\hline $90 I I I$ & 0.079 & 0.069 & 0.097 & 0.094 & 0.115 & 0.047 \\
\hline $91 \mathrm{II}$ & 0.100 & 0.066 & 0.098 & 0.065 & 0.079 & 0.059 \\
\hline $91 \mathrm{II}$ & 0.070 & 0.092 & 0.179 & 0.156 & 0.093 & 0.107 \\
\hline 92 & 0.088 & 0.042 & 0.058 & 0.062 & 0.070 & 0.055 \\
\hline
\end{tabular}

\begin{tabular}{|l|c|c|c|c|c|c|}
\hline \multicolumn{7}{|c|}{ FLOUR } \\
\hline PERIOD & Store 1 & Store 2 & Storc 3 & Storc 4 & Store 5 & CVI \\
\hline $90 \mathrm{I}$ & 0.142 & 0.249 & 0.195 & 0.214 & 0.138 & 0.171 \\
\hline $90 \mathrm{II}$ & 0.020 & 0.086 & 0.045 & 0.105 & 0.095 & 0.059 \\
\hline $90 \mathrm{III}$ & 0.066 & 0.055 & 0.056 & 0.046 & 0.074 & 0.027 \\
\hline $91 \mathrm{I}$ & 0.052 & 0.060 & 0.069 & 0.048 & 0.046 & 0.017 \\
\hline $91 \mathrm{II}$ & 0.013 & 0.009 & 0.011 & 0.008 & 0.008 & 0.009 \\
\hline 92 & 0.026 & 0.020 & 0.074 & 0.024 & 0.021 & 0.023 \\
\hline
\end{tabular}


Inflation and the informativeness of prices

(Cont. Table A3)

\begin{tabular}{|l|c|c|c|c|c|c|}
\hline \multicolumn{7}{|c|}{ OIL } \\
\hline PERIOD & Store 1 & Store 2 & Store 3 & Store 4 & Store 5 & CVI \\
\hline $90 \mathrm{I}$ & 0.199 & 0.202 & 0.203 & 0.155 & 0.182 & 0.176 \\
\hline $90 \mathrm{II}$ & 0.078 & 0.078 & 0.060 & 0.073 & 0.052 & 0.054 \\
\hline $90 \mathrm{III}$ & 0.067 & 0.060 & 0.106 & 0.092 & 0.097 & 0.079 \\
\hline $91 \mathrm{I}$ & 0.052 & 0.059 & 0.049 & 0.306 & 0.034 & 0.025 \\
\hline $91 \mathrm{II}$ & 0.012 & 0.030 & 0.027 & 0.008 & 0.011 & 0.010 \\
\hline 92 & 0.020 & 0.069 & 0.085 & 0.082 & 0.085 & 0.050 \\
\hline
\end{tabular}

\begin{tabular}{|l|c|c|c|c|c|c|}
\hline \multicolumn{7}{|c|}{ RICE } \\
\hline PERIOD & Store 1 & Store 2 & Store 3 & Store 4 & Store 5 & CVI \\
\hline $90 \mathrm{I}$ & 0.115 & 0.169 & 0.163 & 0.192 & 0.124 & 0.226 \\
\hline $90 \mathrm{II}$ & 0.050 & 0.045 & 0.029 & 0.049 & 0.092 & 0.051 \\
\hline $90 \mathrm{III}$ & 0.099 & 0.304 & 0.129 & 0.125 & 0.135 & 0.100 \\
\hline $91 \mathrm{I}$ & 0.076 & 0.304 & 0.050 & 0.072 & 0.102 & 0.046 \\
\hline $91 \mathrm{II}$ & 0.098 & 0.069 & 0.051 & 0.086 & 0.123 & 0.031 \\
\hline 92 & 0.100 & 0.097 & 0.034 & 0.098 & 0.115 & 0.077 \\
\hline
\end{tabular}

\begin{tabular}{|l|c|c|c|c|c|c|}
\hline \multicolumn{7}{|c|}{ TEA } \\
\hline PERIOD & Store 1 & Store 2 & Store 3 & Store 4 & Store 5 & CVI \\
\hline $90 \mathrm{I}$ & 0.115 & 0.252 & 0.259 & 0.155 & 0.216 & 0.147 \\
\hline 9 OII & 0.157 & 0.102 & 0.077 & 0.012 & 0.032 & 0.039 \\
\hline 90 III & 0.084 & 0.052 & 0.045 & 0.023 & 0.033 & 0.018 \\
\hline $91 \mathrm{I}$ & 0.049 & 0.071 & 0.099 & 0.082 & 0.104 & 0.026 \\
\hline $91 \mathrm{II}$ & 0.033 & 0.043 & 0.063 & 0.126 & 0.058 & 0.048 \\
\hline 92 & 0.023 & 0.034 & 0.034 & 0.059 & 0.079 & 0.037 \\
\hline
\end{tabular}


Mariano Tommasi

(Cont. Table A3)

\begin{tabular}{|l|c|c|c|c|c|c|}
\hline \multicolumn{7}{|c|}{ YERBA } \\
\hline PERIOD & Store 1 & Storc 2 & Storc 3 & Storc 4 & Storc 5 & CVI \\
\hline $90 \mathrm{I}$ & 0.029 & 0.085 & 0.042 & 0.067325 & 0.128050 & 0.04296 \\
\hline $90 \mathrm{II}$ & 0.041 & 0.046 & 0.056 & 0.044801 & 0.066252 & 0.02568 \\
\hdashline $90 \mathrm{III}$ & 0.022 & 0.020 & 0.029 & 0.043873 & 0.049335 & 0.01642 \\
\hline $91 \mathrm{I}$ & 0.076 & 0.058 & 0.050 & 0.308714 & 1.187889 & 0.04446 \\
\hline $91 \mathrm{II}$ & 0.062 & 0.008 & 0.021 & 0.447315 & 0.008059 & 0.01709 \\
\hline 92 & 0.027 & 0.079 & 0.052 & 0.191918 & 0.936448 & 0.04387 \\
\hline
\end{tabular}


Inflation and the informativeness of prices

Table A4

Duration of Real Prices

\begin{tabular}{|c|c|c|c|c|c|}
\hline \multicolumn{7}{|c|}{ GOOD 1 } \\
\hline PERIOD & STORE 1 & STORE 2 & STORE 3 & STORE 4 & STORE 5 \\
\hline 90A & 2.166667 & 1.625 & 1.857143 & 1.833333 & 1.0 \\
\hline $90 \mathrm{~B}$ & 1.66667 & 2.0 & 2.142857 & 1.888889 & 1.25 \\
\hline 92 & 6.5 & 2.375 & 5.0 & 6.25 & 6.25 \\
\hline
\end{tabular}

\begin{tabular}{|c|c|c|c|c|c|}
\hline \multicolumn{7}{|c|}{ GOOD 2 } \\
\hline PERIOD & STORE 1 & STORE 2 & STORE 3 & STORE 4 & STORE 5 \\
\hline $90 \mathrm{~A}$ & 1.0 & 1.0 & 1.0 & 1.0 & 1.0 \\
\hline $90 \mathrm{~B}$ & 2.714286 & 4.4 & 4.0 & 1.666667 & 1.777778. \\
\hline 92 & 3.833333 & 3.285714 & 2.714286 & 2.5 & 5.25 \\
\hline
\end{tabular}

\begin{tabular}{|c|c|c|c|c|c|}
\hline \multicolumn{7}{|c|}{ GOOD 3 } \\
\hline PERIOD & STORE 1 & STORE 2 & STORE 3 & STORE 4 & STORE 5 \\
\hline $90 \mathrm{~A}$ & 1.0 & 1.0 & 1.0 & 1.0 & 1.0 \\
\hline $90 \mathrm{~B}$ & 2.0 & 1.555556 & 1.5 & 1.3 & 1.625 \\
\hline 92 & 6.25 & 6.25 & 6.5 & 3.0 .1$. & 4.0 \\
\hline
\end{tabular}

\begin{tabular}{|c|c|c|c|c|c|}
\hline \multicolumn{7}{|c|}{ GOOD 4 } \\
\hline PERIOD & STORE 1 & STORE 2 & STORE 3 & STORE 4 & STORE 5 \\
\hline $90 \mathrm{~A}$ & 1.0 & 1.0 & 1.0 & 1.0 & 1.0 \\
\hline $90 \mathrm{~B}$ & 2.857143 & 4.166667 & 2.85714 .3 & 2.5 & 2.5 \\
\hline 92 & 5.0 & 3.5 & 3.142857 & 5.0 & 6.5 \\
\hline
\end{tabular}

\begin{tabular}{|c|c|c|c|c|c|}
\hline \multicolumn{7}{|c|}{ GOOD 5 } \\
\hline PERIOD & STORE 1 & STORE 2 & STORE 3 & STORE 4 & STORE 5 \\
\hline $90 \mathrm{~A}$ & 1.0 & 1.0 & 1.0 & 1.0 & 1.0 \\
\hline $90 \mathrm{~B}$ & 1.333333 & 1.818182 & 1.5 & 1.272727 & 1.181818 \\
\hline 92 & 4.6 & 3.666667 & 6.0 & 3.5 & 6.0 \\
\hline
\end{tabular}


Mariano Tommasi

(Cont. Table A4)

\begin{tabular}{|c|c|c|c|c|c|}
\hline \multicolumn{7}{|c|}{ GOOD 6 } \\
\hline PERIOD & STORE 1 & STORE 2 & STORE 3 & STORE 4 & STORE 5 \\
\hline $90 \mathrm{~A}$ & 1.0 & 1.0 & 1.0 & 1.0 & 1.0 \\
\hline $90 \mathrm{~B}$ & 3.5 & 5.0 & 1.6 & 2.0 & 2.125 \\
\hline 92 & 3.0 & 2.857143 & 4.8 & 3.0 & 14.0 \\
\hline
\end{tabular}

\begin{tabular}{|c|c|c|c|c|c|}
\hline \multicolumn{7}{|c|}{ GOOD 7 } \\
\hline PERIOD & STORE 1 & STORE 2 & STORE 3 & STORE 4 & STORE 5 \\
\hline 90A & 1.1 & 1.1 & 1.1 & 1.1 & 1.1 \\
\hline $90 \mathrm{~B}$ & 3.285714 & 3.285714 & 2.714286 & 1.7777778 & 2.375 \\
\hline 92 & 3.75 & 9.0 & 6.25 & 3.833333 & 3.833333 \\
\hline
\end{tabular}

\begin{tabular}{|c|c|c|c|c|c|}
\hline \multicolumn{7}{|c|}{ GOOD 8 } \\
\hline PERIOD & STORE 1 & STORE 2 & STORE 3 & STORE 4 & STORE 5 \\
\hline $90 \mathrm{~A}$ & 1.0 & 1.0 & 1.0 & 1.0 & 1.0 \\
\hline $90 \mathrm{~B}$ & 2.333333 & 2.222222 & 2.5 & 2.0 & 2.222222 \\
\hline 92 & 4.4 & 3.5 & 3.2 & 2.857143 & 3.666667 \\
\hline
\end{tabular}

\begin{tabular}{|c|c|c|c|c|c|}
\hline \multicolumn{7}{|c|}{ GOOD 9 } \\
\hline PERIOD & STORE 1 & STORE 2 & STORE 3 & STORE 4 & STORE 5 \\
\hline $90 \mathrm{~A}$ & 1.0 & 1.0 & 1.0 & 1.0 & 1.0 \\
\hline $90 \mathrm{~B}$ & 2.285714 & 2.5 & 1.4 & 1.1 & 2.0 \\
\hline 92 & 3.285714 & 5.75 & 3.0 & 2.714286 & 5.0 \\
\hline
\end{tabular}

\begin{tabular}{|c|c|c|c|c|c|}
\hline \multicolumn{7}{|c|}{ GOOD 10 } \\
\hline PERIOD & STORE 1 & STORE 2 & STORE 3 & STORE 4 & STORE 5 \\
\hline $90 \mathrm{~A}$ & 1.0 & 1.0 & 1.0 & 1.0 & 1.0 \\
\hline $90 \mathrm{~B}$ & 1.636364 & 3.666667 & 2.375 & 1.888889 & 2.0 \\
\hline 92 & 9.0 & 3.142857 & 8.666667 & 3.666667 & 6.0 \\
\hline
\end{tabular}


